\title{
Nanoporous Sorbent Material as an Oral Phosphate Binder and for Aqueous Phosphate, Chromate, and Arsenate Removal
}

Thanapon Sangvanich ${ }^{1}$, Worapol Ngamcherdtrakul' ${ }^{1}$, Richard Lee ${ }^{1}$, Jingga Morry ${ }^{1}$, David Castro',2, Glen E Fryxell ${ }^{3}$ and Wassana Yantase ${ }^{1,2 *}$

${ }^{1}$ Department of Biomedical Engineering, Oregon Health \& Science University (OHSU), Portland, Oregon, USA

${ }^{2}$ PDX Pharmaceuticals, LLC, Lake Oswego, Oregon, USA

${ }^{3}$ Battelle Distinguished Inventor, Kennewick, Washington, USA

\begin{abstract}
Phosphate removal is both biologically and environmentally important. Biologically, hyperphosphatemia is a critical condition in end-stage chronic kidney disease patients. Patients with hyperphosphatemia are treated long-term with oral phosphate binders to prevent phosphate absorption to the body by capturing phosphate in the gastrointestinal (GI) tract followed by fecal excretion. Environmentally, phosphate levels in natural water resources must be regulated according to limits set forth by the US Environmental Protection Agency. By utilizing nanotechnology and ligand design, we developed a new material to overcome limitations of traditional sorbent materials such as low phosphate binding capacity, slow binding kinetics, and negative interference by other anions. A phosphate binder based on ironethylenediamine on nanoporous silica (Fe-EDA-SAMMS) has been optimized for substrates and Fe(III) deposition methods. The Fe-EDA-SAMMS material had a 4-fold increase in phosphate binding capacity and a broader operating $\mathrm{pH}$ window compared to other reports. The material had a faster phosphate binding rate and was significantly less affected by other anions than Sevelamer $\mathrm{HCl}$, the gold standard oral phosphate binder, and $\mathrm{AG}^{\circledR} 1-\mathrm{X} 8$, a commercially available anion exchanger. It had less cytotoxicity to Caco-2 cells than lanthanum carbonate, another prescribed oral phosphate binder. The Fe-EDA-SAMMS also had high capacity for arsenate and chromate, two of the most toxic anions in natural water.
\end{abstract}

Keywords: Arsenate; Chromate; Phosphate; Sorbent; Hyperphosphatemia; Mesoporous silica; Oral phosphate binder

\section{Introduction}

Hyperphosphatemia is common in end-stage chronic kidney disease and dialysis patients totaling in 2 million worldwide [1]. The current prescribed phosphate binders in the market are calcium-based salts (acetate and carbonate), Sevelamer (hydrochloride and carbonate), lanthanum carbonate, aluminium salts and magnesium salts, which account for about $\$ 1$ billion in global annual sales [2]. Yet they have several drawbacks including high risk of hypercalcemia and calcification $[3,4]$, high costs, low-to-moderate efficacy, adverse gastrointestinal effects, and high pill burden [5]. A new oral phosphate binder with high efficacy, low adverse effects, low cost, and low pill burden is needed. Soluble iron based salts have recently been investigated as calcium-free oral phosphate binders. However, in clinical trials, they were linked to diarrhea, boating, and constipation [6]. By employing a nanoporous sorbent, we can strongly attach iron on the benign silica, while maintaining high phosphate binding capacity via the high surface area of the silica. By ligand design of iron (Fe(III)) on ethylenediamine (EDA), we can achieve high phosphate binding efficacy that is less dependent on $\mathrm{pHs}$ and competing anions.

In addition to hyperphosphatemia in patients, excessive amounts of phosphate in water resources can lead to major problems of uncontrolled growth of aquatic plant and algae leading to the depletion of oxygen in aquatic ecosystems and subsequent decline in aquatic living organisms. Phosphate is widely used in industrial, agricultural and household products. The US Environmental Protection Agency (EPA) has limited the phosphate levels to be $<20 \mathrm{mg} / \mathrm{L}$ in rivers, streams [7], lakes and reservoirs [8] and $<2 \mathrm{mg} / \mathrm{L}$ in estuarine and coastal marine waters [9]. There have been extensive efforts in lowering phosphate levels in wastewater to meet these discharge limits. The methods exploited include phosphate adsorption, biological treatment, and chemical precipitation. Chemical precipitation is effective only at high phosphate levels, while biological treatment is very slow, expensive and requires multiple complicated operational processes [10]. Phosphate removal by the right adsorbent materials can have advantages over precipitation and biological processes because it can be effective at low phosphate concentration, it offers fast capture kinetics, it is potentially far less expensive, and it is easy to operate. In this regard, a wide array of materials have been investigated for phosphate removal sorbents such as iron oxide [11], binary metal oxides [12-15], alumina [16,17], chitosan [18,19], and silica-based materials [20-25] as summarized in Table 1. However, the phosphate removal properties of these materials, especially binding capacity, still need improvement. Herein, we report systematic optimization of advanced nanoporous sorbent materials, yielding much better phosphate capture efficiency than previously reported iterations and those of commercial sorbent materials in terms of phosphate binding capacity, capture rate, and less competition from competing anions.

Self-assembled monolayers on mesoporous supports (SAMMS ${ }^{\circledR}$ ) are versatile hybrid materials generated by covalently grafting and cross-linking functional organosilanes to make a dense molecular coating inside nanoporous silica $\left(\mathrm{SiO}_{2}\right)$. By varying the terminal

*Corresponding author: Wassana Yantasee, Department of Biomedical Engineering, OHSU School of Medicine, Mail code: $\mathrm{CH} 13 \mathrm{~B}$, Center of Health and Healing, 3303 SW Bond Ave, Portland, Oregon 97239, USA, Tel: 503-418-9306; Fax: 503-418-9311; E-mail: yantasee@ohsu.edu

Received July 22, 2014; Accepted August 27, 2014; Published September 09, 2014

Citation: Sangvanich T, Ngamcherdtrakul W, Lee R, Morry J, Castro D, et al (2014) Nanoporous Sorbent Material as an Oral Phosphate Binder and for Aqueous Phosphate, Chromate, and Arsenate Removal. J Nanomed Nanotechnol 5: 222 doi: 10.4172/2157-7439.1000222

Copyright: (c) 2014 Sangvanich T, et al. This is an open-access article distributed under the terms of the Creative Commons Attribution License, which permits unrestricted use, distribution, and reproduction in any medium, provided the original author and source are credited. 


\begin{tabular}{|c|c|c|c|c|}
\hline Sorbent & $\mathrm{pH}$ & Temperature $\left({ }^{\circ} \mathrm{C}\right)$ & Adsorption Capacity (mg phosphate/g) & Reference \\
\hline Fe-EDA-SAMMS & 5.0 & 25 & 156.3 & This work \\
\hline Fe-EDA-SAMMS & 5.0 & 25 & 43.3 & [20] \\
\hline $\mathrm{NH}_{3}{ }^{+}$on $\mathrm{MCM}-48$ & $\mathrm{~N} / \mathrm{A}$ & 25 & 47.8 & [21] \\
\hline Fe-EDA on SBA-15 & $\mathrm{N} / \mathrm{A}$ & 35 & 63.4 & [22] \\
\hline Fe-EDA on MCM-41 & 7.0 & 25 & 51.8 & [23] \\
\hline La-EDA on MCM-41 & 7.0 & 25 & 54.3 & [24] \\
\hline Magnetic Fe-Zr binary oxide & 4.0 & 25 & 41.8 & [15] \\
\hline Chitosan hydrogel & 5.0 & 25 & 88.4 & [18] \\
\hline
\end{tabular}

Table 1: Performance comparison of previously reported phosphate removal sorbents in DI water.

organic functionality, SAMMS materials have been tailored to selectively capture oxometallate anions $[20,26]$, toxic heavy metals [2732], transition metals [33,34], lanthanides and actinides [35-40], and cesium and thallium [41-43]. For environmental phosphate removal, we have developed an iron functionalized nanoporous silica (FeEDA-SAMMS) [20], but its capacity needed improvement. Herein, we report the optimized synthesis of Fe-EDA-SAMMS to improve binding capacity (by 4 -fold) and other characteristics, demonstrating Fe-EDASAMMS to be very highly attractive as an environmental phosphate removal sorbent and as an oral phosphate binder.

\section{Materials and Methods}

\section{Chemicals and reagents}

Potassium phosphate $\left(\mathrm{KH}_{2} \mathrm{PO}_{4}\right.$ and $\left.\mathrm{K}_{2} \mathrm{HPO}_{4}\right)$, potassium chromate $\left(\mathrm{K}_{2} \mathrm{CrO}_{4}\right)$, sodium arsenate $\left(\mathrm{Na}_{2} \mathrm{HAsO}_{4} \cdot 7 \mathrm{H}_{2} \mathrm{O}\right)$, sodium chloride $(\mathrm{NaCl})$, sodium nitrate $\left(\mathrm{NaNO}_{3}\right)$, sodium bicarbonate $\left(\mathrm{NaHCO}_{3}\right)$, sodium sulfate $\left(\mathrm{Na}_{2} \mathrm{SO}_{4}\right)$, sodium citrate $\left(\mathrm{Na}_{3} \mathrm{C}_{6} \mathrm{H}_{5} \mathrm{O}_{7} \cdot 2 \mathrm{H}_{2} \mathrm{O}\right)$, sodium acetate $\left(\mathrm{NaC}_{2} \mathrm{H}_{3} \mathrm{O}_{2}\right)$, potassium chloride $(\mathrm{KCl})$, dimethoxyethane (glyme), [3-(2-aminoethylamino)propyl] trimethoxysilane, $25-\mathrm{kDa}$ branched polyethyleneimine (PEI), Cab-o-sil ${ }^{\circ}$ M5 and StratoSpheres ${ }^{\mathrm{Tm}}$ PL-EDA polystyrene resin were purchased from Sigma Aldrich (St. Louis, $\mathrm{MO})$. Ferric chloride $\left(\mathrm{FeCl}_{3} \cdot 6 \mathrm{H}_{2} \mathrm{O}\right)$, acetonitrile $\left(\mathrm{CH}_{3} \mathrm{CN}\right)$, methanol, 2-propanol, dimethyl sulfoxide (DMSO), sodium hydroxide $(\mathrm{NaOH})$, hydrochloric acid $(\mathrm{HCl})$ and nitric acid $\left(\mathrm{HNO}_{3}\right)$ were purchased from Fisher Scientific (Waltham, MA). Ultrapure SiliaBond Diamine functionalized silica gel was purchased from Silicycle (Quebec City, QC). 3-isocyanatopropyl trimethoxysilane was purchased from Gelest (Morrisville, PA). Sevelamer $\mathrm{HCl}$ was purchased from Genzyme (Cambridge, $\mathrm{MA}$ ) and $\mathrm{AG}^{\circ} 1-\mathrm{X} 8$ anion exchanger was purchased from BioRad (Hercules, CA). All common chemicals and reagents were of high purity grade.

\section{Material synthesis}

Details for synthesis of EDA-SAMMS was described in our previous work $[20,26]$. Briefly, pre-hydrated MCM-41 (with a surface area of $880 \mathrm{~m}^{2} / \mathrm{g}$ and average pore size of $48 \AA$ ) was treated with [3-(2-aminoethylamino)propyl] trimethoxysilane in refluxing toluene for $6 \mathrm{~h}$ to obtain EDA-SAMMS. Fe(III) was incorporated onto the EDA-SAMMS by mixing Fe(III) solution with EDA-SAMMS. Fe(III) solution was prepared by dissolving $\mathrm{FeCl}_{3} \cdot 6 \mathrm{H}_{2} \mathrm{O}$ in either de-ionized (DI) water or acetonitrile at a concentration of $5 \mathrm{wt} \%$. Ten grams of EDA-SAMMS was mixed with $50 \mathrm{~mL}$ of $\mathrm{Fe}(\mathrm{III})$ solution resulting in Fe per EDA-SAMMS mass ratio of 0.52 . The reaction was conducted at either room temperature or $65^{\circ} \mathrm{C}$ for a duration of $1 \mathrm{~h}$ or $20 \mathrm{~h}$. The resulting Fe-EDA-SAMMS was then washed extensively with DI water and 2-propanol to remove unbound $\mathrm{Fe}(\mathrm{III})$, air-dried and stored at room temperature until use.

For comparison, using the same conditions, Fe(III) was also incorporated into two other commercial ethylenediamine (EDA)functionalized substrates: EDA-resin (StratoSpheres ${ }^{\mathrm{Tw}}$ PL-EDA polystyrene resin) and EDA-porous silica gel (SiliaBond ${ }^{\circ}$ Diamine).

Lastly, as an alternative to EDA, polyethyleneimine (PEI), having abundant amine groups, was grafted onto the surface of non-porous fumed silica (Cab-o-sil M5). Briefly, $5.2 \mathrm{~g}$ of $25-\mathrm{kDa}$ branched PEI was pre-treated with $60 \mathrm{~mL}$ of DMSO in $60 \mathrm{~mL}$ of warm glyme $\left(40-50^{\circ} \mathrm{C}\right)$ for $2 \mathrm{~h}$. The warm mixture was treated with $120 \mu \mathrm{L}$ of 3-isocyanatopropyl trimethoxysilane, then $3 \mathrm{~g}$ of the fumed silica was immediately added into the modified PEI mixture and stirred overnight under static nitrogen atmosphere. The material, PEI-fumed silica, was then washed with copious amount of methanol and air-dried. The Fe(III) incorporation was then conducted in the same manner as previously described.

\section{Batch contact experiments}

Sorbent materials developed in our lab as well as commercially available materials, Sevelamer $\mathrm{HCl}$ and $\mathrm{AG}^{\circ} 1-\mathrm{X} 8$ anion exchanger, were tested in batch contact experiments as described in our previous work [20]. Briefly, known weights of sorbent material were added into a phosphate solution prepared from $\mathrm{KH}_{2} \mathrm{PO}_{4}$ with a concentration range from $3 \mathrm{mg} / \mathrm{L}$ to $3000 \mathrm{mg} / \mathrm{L}$ of phosphate in a polypropylene vial to achieve a liquid-to-solid ratio (L/S) of $200,1,000$ or $2,000 \mathrm{~mL} / \mathrm{g}$. Batch contact was carried out on an orbital shaker $(200 \mathrm{rpm})$ for $2 \mathrm{~h}$ and then filtered prior to analysis. Phosphate concentration of the filtrates was analyzed with inductively-coupled plasma mass spectrometer (ICPMS) Agilent 7700c (Agilent, Santa Clara, CA). All experiments were performed with control (same solutions without sorbents added) in parallel and in triplicate. Sorbents' ability to capture phosphate was reported in terms of percentage of phosphate removal from the solution (Equation 1) or amount of phosphate adsorbed per gram of sorbent material (Equation 2):

$$
\text { Phosphateremoval }(\%)=100 \times \frac{C_{0}-C_{e}}{C_{0}}
$$

where $\mathrm{C}_{0}$ and $\mathrm{C}_{\mathrm{e}}$ are the initial and equilibrium concentrations of phosphate, respectively (in $\mathrm{mg} / \mathrm{L}$ ).

$$
\text { Phosphate adsorbed }\left(\frac{m g \text { phosphate }}{g \text { sorbent }}\right)=\left(C_{0}-C_{e}\right) \times L / S
$$

where $\mathrm{L} / \mathrm{S}$ is the liquid-to-solid ratio (in $\mathrm{mL} / \mathrm{g}$ ).

Typical testing conditions were $3 \mathrm{mg} / \mathrm{L}$ of phosphate prepared from $\mathrm{KH}_{2} \mathrm{PO}_{4}$ in DI water and $\mathrm{pH}$ of 5.3. In anion competition study, test matrices include chloride, nitrate, bicarbonate, acetate, sulfate and citrate; all from sodium salts. In the $\mathrm{pH}$-dependent phosphate capture study, $6 \mathrm{mg} / \mathrm{L}$ phosphate solution was prepared from $\mathrm{K}_{2} \mathrm{HPO}_{4}$; its $\mathrm{pH}$ was adjusted to $1.0-12.0$ with $0.1 \mathrm{M} \mathrm{HCl}$ or $0.10-1.0 \mathrm{M} \mathrm{NaOH}$.

Furthermore, for evaluating the materials as potential oral phosphate binders, simulated gastric fluid (SGF) and simulated intestinal fluid 


\begin{tabular}{|c|c|c|c|c|c|c|c|c|}
\hline \multirow{2}{*}{ Iteration } & \multicolumn{4}{|c|}{ Fe Incorporation conditions } & \multirow{2}{*}{$\begin{array}{l}\text { Fe content } \\
(\mathrm{mmol} / \mathrm{g})\end{array}$} & \multicolumn{3}{|c|}{ \% Phosphate Removal } \\
\hline & Fe:EDA SAMMS (mass) & Solvent & Temperature $\left({ }^{\circ} \mathrm{C}\right)$ & Time (h) & & SGF, pH 1.1 (b) & SIF, pH 4.0 (c) & SIF, pH 6.5 (c) \\
\hline I [20] & 0.023 & Water & $25^{\circ} \mathrm{C}$ & 1 & 0.83 & $34 \pm 5$ & $63 \pm 2$ & $14 \pm 4$ \\
\hline II & 0.52 & Water & $25^{\circ} \mathrm{C}$ & 1 & $0.017 \pm 0.000$ & $5 \pm 2$ & $58 \pm 2$ & $74 \pm 1$ \\
\hline III & 0.52 & Acetonitrile & $25^{\circ} \mathrm{C}$ & 1 & $0.122 \pm 0.003$ & $51 \pm 4$ & $83 \pm 1$ & $61 \pm 2$ \\
\hline IV & 0.52 & Acetonitrile & $65^{\circ} \mathrm{C}$ & 1 & $0.140 \pm 0.013$ & $75 \pm 2$ & $96 \pm 1$ & $98 \pm 1$ \\
\hline $\mathrm{V}$ & 0.52 & Acetonitrile & $65^{\circ} \mathrm{C}$ & 20 & $0.224 \pm 0.015$ & $93 \pm 0$ & $96 \pm 1$ & $93 \pm 1$ \\
\hline VI & $\mathrm{N} / \mathrm{A}$ & Acetonitrile & $65^{\circ} \mathrm{C}$ & 20 & N/A & $0 \pm 0$ & $19 \pm 2$ & $8 \pm 3$ \\
\hline
\end{tabular}

(a)Initial phosphate concentration of $3 \mathrm{mg}$ phosphate/ $\left(\right.$ from $\mathrm{KH}_{2} \mathrm{PO}_{4}$ ), $\mathrm{L} / \mathrm{S}$ ratio of $1000 \mathrm{~mL} / \mathrm{g}$

(b) SGF, pH 1.1, consists of $0.03 \mathrm{M} \mathrm{NaCl}$ and $0.085 \mathrm{M} \mathrm{HCl}$

(c)SIF, pH 4.0 and 6.5 , consist of $0.14 \mathrm{M} \mathrm{NaCl}, 0.005 \mathrm{M} \mathrm{KCl}, 0.008 \mathrm{M} \mathrm{NaHCO}_{3}$, pH adjusted with $0.1 \mathrm{M} \mathrm{HCl}$

Table 2: Phosphate removal efficiency of Fe-EDA-SAMMS ${ }^{(a)}$.

(SIF) were also used as the test matrices. Both SGF and SIF were prepared following the recommendations of the U.S. Pharmacopeia for drug dissolution studies in stomach and intestine $[44,45]$. The SGF $(\mathrm{pH}$ 1.1) contained $0.03 \mathrm{M} \mathrm{NaCl}$ and $0.085 \mathrm{M} \mathrm{HCl}$. The SIF contained 0.14 $\mathrm{M} \mathrm{NaCl}, 0.005 \mathrm{M} \mathrm{KCl}$ and $0.008 \mathrm{M} \mathrm{NaHCO}_{3}$; its $\mathrm{pH}$ was adjusted to 4.0 and 6.5 with $0.1 \mathrm{M} \mathrm{HCl}$. An additional SIF solution containing $0.08 \mathrm{M}$ $\mathrm{NaCl}$ and $0.03 \mathrm{M} \mathrm{NaHCO}_{3}$ with $\mathrm{pH}$ adjusted to 6.6 was also used [46].

\section{Sorption capacity}

The sorption capacity of Fe-EDA-SAMMS was measured in batch contact at room temperature. Phosphate, arsenate, and chromate solutions with varying concentrations from 0 to $700 \mathrm{mg} / \mathrm{L}$ were in contact with the sorbent at an $\mathrm{L} / \mathrm{S}$ ratio of $2000 \mathrm{~mL} / \mathrm{g}$ for $2 \mathrm{~h}$ assuring equilibrium condition. Langmuir isotherm equation was used to fit sorption capacity data as shown in Equation 3.

$$
Q_{e}=\frac{K_{L} Q_{\max } C_{e}}{1+K_{L} C_{e}}
$$

where $\mathrm{C}_{\mathrm{e}}, \mathrm{Q}_{\mathrm{e}}, \mathrm{Q}_{\max }$ and $\mathrm{K}_{\mathrm{L}}$ are equilibrium concentration (in $\mathrm{mg} / \mathrm{L}$ ), equilibrium uptake (in $\mathrm{mg} / \mathrm{g}$ ), maximum binding capacity (in $\mathrm{mg} / \mathrm{g}$ ) and Langmuir constant (in $\mathrm{L} / \mathrm{mg}$ ), respectively.

\section{Sorption kinetics}

The kinetics of phosphate capture was measured in a modified batch contact experiment. Briefly, a $50 \mathrm{~mL}$ solution of $3 \mathrm{mg} / \mathrm{L}$ phosphate was mixed with $0.5 \mathrm{~g}$ sorbent at an $\mathrm{L} / \mathrm{S}$ ratio of $1000 \mathrm{~mL} / \mathrm{g}$. At each designated time point; $1,2.5,5,10,30,60,120$ and $240 \mathrm{~min}, 1.5 \mathrm{~mL}$ of mixture was collected, filtered, and subjected to phosphate analysis by ICP-MS. The sorption kinetics were measured in both DI water and SIF (0.14 M NaCl, $0.005 \mathrm{M} \mathrm{KCl}$ and 0.008 $\left.\mathrm{M} \mathrm{NaHCO}_{3}, \mathrm{pH} 6.3\right)$.

\section{Flow removal of phosphate and regeneration of Fe-EDA- SAMMS}

Ten cycles of adsorption and desorption were performed on FeEDA-SAMMS to test its regeneration and reuse ability in a flow-through system. For the adsorption step, $10 \mathrm{~mL}$ of a $3 \mathrm{mg} / \mathrm{L}$ phosphate solution was passed through a fixed bed of $0.01 \mathrm{~g}$ Fe-EDA-SAMMS at the flow rate of $2 \mathrm{~mL} / \mathrm{min}$, and the outlet solution was collected for phosphate analysis by ICP-MS. Next, $10 \mathrm{~mL}$ of DI water was passed through the bed to remove residual unbound phosphate. For the desorption step, $10 \mathrm{~mL}$ of $0.2 \mathrm{M} \mathrm{HCl}$ was passed through the bed at $2 \mathrm{~mL} / \mathrm{min}$ and the outlet solution was collected for phosphate analysis. A $10 \mathrm{~mL}$ of DI water was then passed through to remove residual acid. Lastly, $10 \mathrm{~mL}$ of $0.01 \mathrm{M}$ sodium acetate was passed through to $\mathrm{pH}$-equilibrate the $\mathrm{Fe}$ EDA-SAMMS at a flow rate of $2 \mathrm{~mL} / \mathrm{min}$ followed by a $10 \mathrm{~mL}$ of DI water wash. The cycle was repeated 10 times on the same sorbent bed.

\section{Cell culture and cytotoxicity study}

Immortal human colon epithelial cells, Caco-2, were obtained from American Type Culture Collection (Manassas, VA). Cell stocks were cultured in DMEM (Corning/Cellgro, Manassas, VA) supplemented with $10 \%$ fetal bovine serum (GIBCO, Life Technologies, Grand Island, NY) and 1X penicillin/streptomycin (Corning/Cellgro, Manassas, VA) at $37^{\circ} \mathrm{C}$ in $5 \% \mathrm{CO}_{2}$ atmosphere. For cytotoxicity assays, cells were seeded at 3000 cells/well in 96-well flat-bottomed plates and grown to optimal confluency in 5 days. Cells were then exposed to Fe-EDASAMMS, Sevelamer HCl (Renagel, Genzyme, MA) or lanthanum carbonate (Fosrenol, Shire Pharmaceuticals, Dublin) at a dose of 500, 1000,2500 and $5000 \mu \mathrm{g} / \mathrm{mL}$ for $24 \mathrm{~h}$ and $48 \mathrm{~h}$. After the designated time, cell viability was quantified with the CellTiter-Glo Luminescent Cell Viability Assay (Promega, Madison, WI) and normalized to an untreated control (without phosphate binder added).

\section{Results and Discussion}

\section{Optimization of $\mathrm{Fe}(\mathrm{III})$ incorporation}

Varied conditions of Fe(III) incorporation onto EDA-SAMMS and the phosphate binding ability of the resulting materials are summarized in Table 2. In an attempt to increase the Fe loading on EDA-SAMMS, we increased the amount of initial $\mathrm{Fe}$ (III) in the solution by 20 -fold compared to our earlier work (Iteration I) [20]. However, this did not result in increased Fe loading $(0.83 \mathrm{mmol} / \mathrm{g}$ vs. $0.017 \mathrm{mmol} / \mathrm{g})$. This is likely due to the fact that the $\mathrm{pH}$ of the loading solution dropped at the higher $\mathrm{Fe}(\mathrm{III})$ concentration (i.e., from $\mathrm{pH} 1.96$ to 1.46), and the EDA-SAMMS are more likely to be protonated under the more acidic conditions. Accordingly, the phosphate capture did not improve under the SGF ( $\mathrm{pH} 1.1$ ) and SIF ( $\mathrm{pH}$ 4.0) test matrices. To avoid fighting the $\mathrm{pH}$ issues associated with aqueous solutions of $\mathrm{Fe}$ (III) ion, we employed acetonitrile as our solvent for the Fe incorporation. As an anhydrous, polar aprotic solvent, acetonitrile does not have any readily dissociable protons to increase the acidity of the reaction mixture upon dissolution of $\mathrm{Fe}(\mathrm{III})$ salts, resulting in no competing protonation of the EDA ligand. This solvent change led to a 7-fold increase in $\mathrm{Fe}$ loading after $1 \mathrm{~h}$ of contact time (Iteration III), which is associated with improved phosphate removal efficacy. Next we show that increasing the temperature of $\mathrm{Fe}(\mathrm{III})$ in acetonitrile from room temperature to $65^{\circ} \mathrm{C}$ (Iteration IV) and contact time from $1 \mathrm{~h}$ to $20 \mathrm{~h}$ (Iteration V), we could substantially increase Fe loading to 0.140 , and $0.224 \mathrm{mmol} / \mathrm{g}$, respectively. The high reaction temperature and increased reaction time helped overcome kinetic barriers associated with charge accumulation (i.e., cation-cation repulsion) within the monolayer, thereby facilitating integration of $\mathrm{Fe}$ into the EDA monolayer inside the pores of SAMMS. The most optimal Fe-EDA-SAMMS (Iteration V) achieved $93-96 \%$ of phosphate removal in all three matrices. However, increasing the 


\begin{tabular}{|c|c|c|c|c|c|c|}
\hline Material $^{(\mathbf{b})}$ & Capacity (mg/g) & $\mathrm{N}$ content $(\mathrm{mmol} / \mathrm{g})$ & Fe content $(\mathrm{mmol} / \mathrm{g})$ & $\begin{array}{c}\text { Specific surface area }{ }^{(\mathrm{c})} \\
\left(\mathrm{m}^{2} / \mathrm{g}\right)\end{array}$ & Pore $\operatorname{size}^{(\mathrm{c})}(\AA)$ & Particle size ${ }^{(c)}(\mu \mathrm{m})$ \\
\hline Fe-EDA-SAMMS & $157 \pm 6$ & $2.64 \pm 0.06$ & $0.224 \pm 0.015$ & 880 & 48 & $20-75$ \\
\hline Fe-EDA-resin & $126 \pm 3$ & $6.35^{(\mathrm{b})}$ & $0.053 \pm 0.005$ & N/A & N/A & $194^{(\mathrm{d})}$ \\
\hline Fe-EDA-porous silica gel & $66 \pm 5$ & $1.98 \pm 0.02$ & $0.113 \pm 0.014$ & $500^{(d)}$ & $60^{(\mathrm{d})}$ & $40-63^{(d)}$ \\
\hline Fe-PEl-fume silica & $45 \pm 5$ & $6.97 \pm 0.23$ & $0.047 \pm 0.001$ & $200^{(e)}$ & N/A & $0.2-0.3^{(\mathrm{e})}$ \\
\hline
\end{tabular}

(a)Initial phosphate concentration of $3.0 \mathrm{~g}$ phosphate/L (from $\mathrm{KH}_{2} \mathrm{PO}_{4}$ ) in $\mathrm{SIF}(0.08 \mathrm{M} \mathrm{NaCl}, 0.03 \mathrm{M} \mathrm{NaHCO})$ pH 6.60 , $\mathrm{L} / \mathrm{S}$ ratio of $200 \mathrm{~mL} / \mathrm{g}$

${ }^{(b)}$ EDA-resin (StratoSpheres ${ }^{\text {TM }}$ PL-EDA), EDA-porous silica gel (SiliaBond ${ }^{\circledR}$ Diamine), fumed silica (Cab-o-sil ${ }^{\circledR}$ )

(c) Specific surface area, pore size and particle size are of substrates.

(d) Data from manufacturer's certificate of analysis

${ }^{(e)}$ Data from manufacturer's product specification sheet

Table 3: Phosphate removal capacity of Fe-amine on various substrates ${ }^{(a)}$

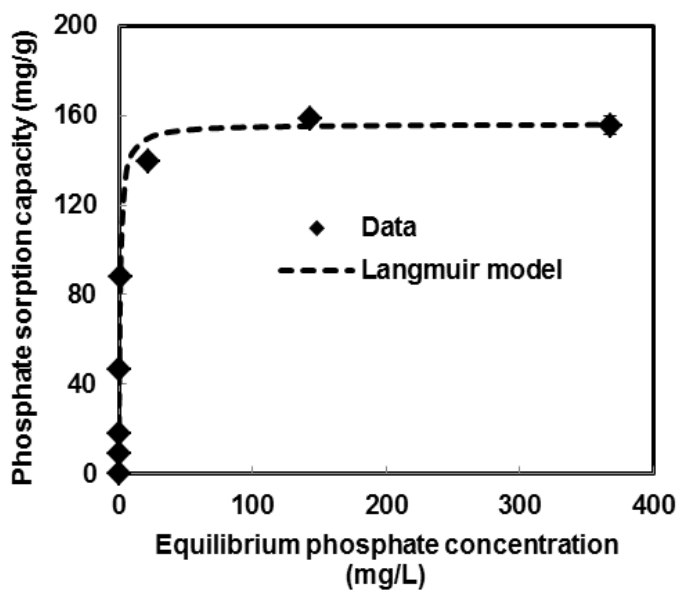

Figure 1: Adsorption isotherm of phosphate on Fe-EDA-SAMMS in DI water ( $\mathrm{pH}$ 5.3), L/S of $2000 \mathrm{~mL} / \mathrm{g}$, symbols represent data and dash-line represents Langmuir isotherm fitting.

temperature of reaction to boiling point $\left(82^{\circ} \mathrm{C}\right)$ of acetonitrile did not further increase phosphate removal efficacy of the material (data not shown). It is worth noting that, although Fe loading of original material (Iteration I) was extremely high $(0.83 \mathrm{mmol} \mathrm{Fe} / \mathrm{g})$ compared to others, it did not yield the best phosphate capture perhaps due to the iron oxide formation which did not attribute to the phosphate adsorption of the material. A control experiment (Iteration VI) was carried out similarly to Iteration $\mathrm{V}$ but without $\mathrm{Fe}$ (III) in the solution. The Iteration VI material likely contained protonated EDA as a functional group (occurring during material washing step with DI water), but had much lower phosphate removal in all matrices compared to Iteration $\mathrm{V}$. This indicates the advantage of $\mathrm{Fe}(\mathrm{III})$-EDA over protonated amine for phosphate binder in these three matrices. In summary, the incorporation of Fe(III) onto EDA-SAMMS was found to be optimum when carried out in acetonitrile solvent, at $65^{\circ} \mathrm{C}$ for $20 \mathrm{~h}$ using $\mathrm{Fe}(\mathrm{III})$ solution of 1-5 wt $\%$. This protocol was hence used in all subsequent studies.

\section{Optimization of amine functionalized substrates}

To achieve the best overall sorbent for binding phosphate, it is important to optimize not only the interfacial binding chemistry, but also the substrates (supports) which can impact phosphate binding capacity and rate. In this regard, we compared four amine-functionalized substrates: EDA-resin (StratoSpheres ${ }^{\text {rt }}$ PL-EDA), EDA-porous silica gel (SiliaBond Diamine), PEI-fumed silica (on Cab-o-Sil M5), and EDASAMMS (on MCM-41). All were incorporated with Fe(III) using the optimal incorporation conditions previously described. These materials varied in particle size, pore size, surface area, amine functional group
(EDA or PEI) loading, and Fe loading as shown in Table 3. Their phosphate removal capabilities were measured in SIF $(0.08 \mathrm{M} \mathrm{NaCl}$, $0.03 \mathrm{M} \mathrm{NaHCO}_{3}, \mathrm{pH} 6.6$ ) with about $3.0 \mathrm{~g}$ phosphate/L at an $\mathrm{L} / \mathrm{S}$ ratio of $200 \mathrm{~mL} / \mathrm{g}$ and reported in Table 3 .

Although the EDA-resin has higher EDA loading than our EDASAMMS (6.35 vs. $2.64 \mathrm{mmol} / \mathrm{g}$ ), it exhibited lower Fe loading ( 0.053 vs. $0.224 \mathrm{mmol} \mathrm{Fe} / \mathrm{g})$, which in turn resulted in lower phosphate removal capacity (126 vs. $157 \mathrm{mg} / \mathrm{g}$ ). This lower Fe loading may be due to limitations on the transport of the highly charged Fe(III) ion into the relatively nonpolar core of the polystyrene resin bead. The EDA-porous silica gel has comparable EDA loading with our SAMMS (1.98 vs. 2.64 $\mathrm{mmol} \mathrm{N} / \mathrm{g}$ ), but could load only half the amount of $\mathrm{Fe}$, resulting in $58 \%$ less phosphate removal capacity compared to our Fe-EDA-SAMMS. The synthesis process of this EDA-porous silica gel may result in a high level of self-reaction between the amine groups or the amine groups on the ligands could react with the hydroxyl groups $(\mathrm{OH})$ on the silica surface resulting in less active EDA groups for $\mathrm{Fe}(\mathrm{III})$ to bind to, leading to lower phosphate binding capacity. This was not the case with EDASAMMS since the amount of EDA ligands used was limited by design to only a monolayer deposition.

To increase phosphate binding capacity, branched PEI (25-kDa) was investigated as an alternate to EDA since it contains a high content of amines. $25-\mathrm{kDa}$ PEI was too big to be loaded effectively inside the pores, and hence was loaded on fumed silica (Cab-o-sil M5). The fumed silica is a non-porous material, thus the PEI was loaded on the external surface. We hypothesize that the lower surface area of fumed silica in comparison to SAMMS could be compensated by the considerably higher amount of amine groups of PEI than that of EDA. Despite the substantial surface area of fumed silica $\left(200 \mathrm{~m}^{2} / \mathrm{g}\right)$ and the high loading of PEI (6.97 mmol N/g), PEI-fumed silica had low Fe loading $(0.047 \mathrm{mmol} \mathrm{Fe} / \mathrm{g})$ and the resulting material (Fe-PEIfumed silica) yielded low phosphate binding capacity compared to FeEDA-SAMMS (45 vs. $157 \mathrm{mg} / \mathrm{g}$ ). This is mostly due to PEI wrapping around fumed silica in thick layers, preventing the penetration of both $\mathrm{Fe}$ (III) and phosphate to the available amine groups in the inner layers. Only the outer layer amine groups remained active, resulting in low Fe loading and low phosphate binding capacity. Based on the finding in Table 3, SAMMS, produced from MCM-41, proved to be the best substrate for Fe-amine loading, yielding the highest phosphate binding capacity. It was therefore used in all subsequent experiments.

\section{Adsorption isotherm}

The phosphate binding capacity of Fe-EDA-SAMMS was established with adsorption isotherm experiments conducted in DI water ( $\mathrm{pH}$ 5.3) with an $\mathrm{L} / \mathrm{S}$ ratio of $2000 \mathrm{~mL} / \mathrm{g}$ and room temperature. The phosphate uptake of Fe-EDA-SAMMS increased sharply with increasing initial concentrations of phosphate from 0 to $90 \mathrm{mg} / \mathrm{L}$ (or $22 \mathrm{mg} / \mathrm{L}$ of equilibrium concentration) and began to saturate thereafter. 
Page 5 of 9

\begin{tabular}{|c|c|c|c|c|c|}
\hline \multirow[b]{2}{*}{ Matrix } & \multirow[b]{2}{*}{ Initial pH } & \multicolumn{2}{|c|}{ Fe-EDA-SAMMS } & \multicolumn{2}{|c|}{$A G^{\circledR 1-X 8}$} \\
\hline & & Equilibrium pH & Phosphate removal (\%) & Equilibrium pH & Phosphate removal (\%) \\
\hline $0.00003 \mathrm{M}$ phosphate & 5.6 & 3.6 & $99.5 \pm 0.0$ & 9.6 & $99.8 \pm 0.2$ \\
\hline$+0.01 \mathrm{M}$ sodium chloride & 5.5 & 3.8 & $97.7 \pm 0.3$ & 11.2 & $79.8 \pm 9.6$ \\
\hline$+0.01 \mathrm{M}$ sodium nitrate & 5.7 & 3.9 & $93.8 \pm 0.5$ & 11.3 & $67.5 \pm 10.6$ \\
\hline + $0.01 \mathrm{M}$ sodium bicarbonate & 8.7 & 7.7 & $28.7 \pm 5.7$ & 9.4 & $29.1 \pm 1.0$ \\
\hline$+0.01 \mathrm{M}$ sodium sulfate & 5.7 & 5.8 & $24.2 \pm 0.8$ & 11.0 & $0.0 \pm 0.6$ \\
\hline$+0.01 \mathrm{M}$ sodium citrate & 7.2 & 7.2 & $25.3 \pm 3.2$ & 10.7 & $1.3 \pm 0.3$ \\
\hline
\end{tabular}

(a)Initial phosphate concentration of $3 \mathrm{mg}$ phosphate/L $\left(0.00003 \mathrm{M}\right.$ from $\left.\mathrm{KH}_{2} \mathrm{PO}_{4}\right), \mathrm{L} / \mathrm{S}$ ratio of $1000 \mathrm{~mL} / \mathrm{g}$.

Table 4: Effect of coexisting anions on phosphate removal by Fe-EDA-SAMMS and AG® 1-X8 anion exchanger resin ${ }^{(a)}$.
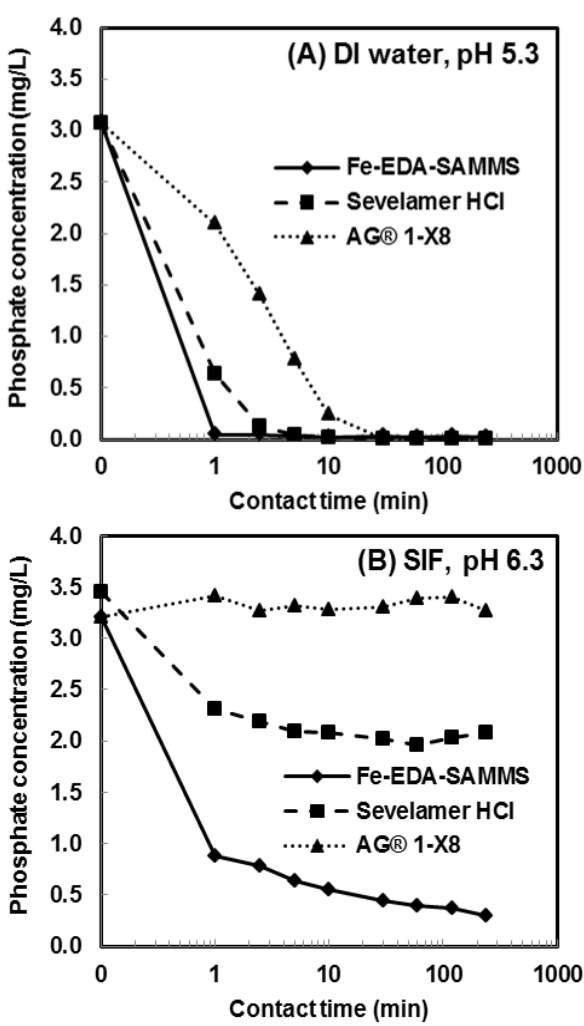

Figure 2: Phosphate adsorption kinetics on Fe-EDA-SAMMS, Sevelamer $\mathrm{HCl}$ and $A G^{\circledR} 1-\mathrm{X} 8$ in $\mathrm{DI}$ water $(\mathrm{A}) \mathrm{pH} 5.3$ and in SIF (B) pH 6.3, L/S ratio of 1000 $\mathrm{mL} / \mathrm{g}$

The adsorption data fitted the Langmuir adsorption model quite nicely, as shown in Figure $1\left(\mathrm{R}^{2}>0.999\right)$. This confirmed that phosphate adsorption on the Fe-EDA-SAMMS followed a monolayer adsorption model similar to the original Fe-EDA-SAMMS previously reported [20]. However, the new Fe-EDA-SAMMS offered much higher phosphate binding capacity at $156 \mathrm{mg}$ phosphate/g sorbent ( $1.65 \mathrm{mmol} / \mathrm{g}$ sorbent), which is almost 4 times higher than that of the older version $(43.3 \mathrm{mg}$ phosphate/g). This binding capacity measured in DI water was the same with that measured in SIF (Table 3), indicating little dependency of matrix effect. The phosphate adsorption capacity is also significantly higher than other sorbents for phosphate capture reported by others (Table 1), which are $47.8 \mathrm{mg} / \mathrm{g}$ for ammonium-functionalized MCM48 [21], $63.4 \mathrm{mg} / \mathrm{g}$ for Fe-diamino-functionalized SBA-15 [22], 54.3 $\mathrm{mg} / \mathrm{g}$ for lanthanum-diamino-functionalized MCM-41 [24], $51.8 \mathrm{mg} / \mathrm{g}$ for Fe-diamino-functionalized MCM-41 [23], $41.8 \mathrm{mg} / \mathrm{g}$ for magnetic $\mathrm{Fe}-\mathrm{Zr}$ binary oxide [15], and $88.4 \mathrm{mg} / \mathrm{g}$ for chitosan hydrogel [18]. All phosphate binding capacities reported were measured in DI water.

\section{Adsorption kinetics}

A fast adsorption rate is highly desirable for field-deployment of sorbent materials, especially for flow system operations. Likewise, for oral phosphate binders, fast phosphate capture (onto the sorbent) reduces the degree of phosphate available to be absorbed into the body. The adsorption kinetics of Fe-EDA-SAMMS was measured in $3 \mathrm{mg}$ phosphate/L in DI water ( $\mathrm{pH} 5.3$ ) with an L/S of $1000 \mathrm{~mL} / \mathrm{g}$ as shown in Figure 2A. We also benchmarked against two commercially available materials: Sevelamer $\mathrm{HCl}$ (the gold standard oral phosphate binder) and $A G^{\circ} 1-\mathrm{X} 8$ resin (a commercial anion exchange resin). Both materials had slower phosphate binding kinetics than Fe-EDASAMMS. Specifically, while Fe-EDA-SAMMS removed over $98.7 \%$ of phosphate in $1 \mathrm{~min}$, Sevelamer $\mathrm{HCl}$ and $\mathrm{AG}^{\circ} 1-\mathrm{X} 8$ only removed $79.2 \%$ and $31.7 \%$, respectively. To remove more than $99 \%$ of phosphate, Fe-EDA-SAMMS took $5 \mathrm{~min}$, while Sevelamer $\mathrm{HCl}$ took $10 \mathrm{~min}$ and $\mathrm{AG}^{\circ} 1$-X8 resin took $30 \mathrm{~min}$. Similar to our previous reports on other types of SAMMS materials [20,34,36-39,42], fast kinetics is a signature of SAMMS performance, which is owed to the rigid and open pore structure, allowing easy access of metal ions to the binding sites inside the pores. These unique characteristics of SAMMS provides advantages over other recently developed phosphate removal materials, which require much longer time to reach equilibrium (e.g., more than $24 \mathrm{~h}$ for $\mathrm{Fe}-\mathrm{Zr}$ binary oxide [15] or $7 \mathrm{~h}$ for chitosan hydrogel [18]). The binding kinetics on SAMMS was slightly affected by the coexisting anions (Figure 2B), to be described in subsequent section.

\section{Effect of coexisting anions}

Wastewaters and other natural waters typically contain several coexisting anions such as chloride $\left(\mathrm{Cl}^{-}\right)$, nitrate $\left(\mathrm{NO}_{3}^{-}\right)$, bicarbonate $\left(\mathrm{HCO}_{3}^{-}\right)$and sulfate $\left(\mathrm{SO}_{4}^{2-}\right)$, whereas the most common anion species in the gastrointestinal tract are chloride $(0.10-0.13 \mathrm{M})$ and bicarbonate $(0.006-0.040 \mathrm{M})$ [47]. These anions can compete with phosphate for Fe-EDA binding sites. The effect of coexisting anions was measured in $3 \mathrm{mg} / \mathrm{L}$ phosphate solution $(0.00003 \mathrm{M})$ and $0.01 \mathrm{M}$ coexisting anions, including chloride, nitrate, bicarbonate, sulfate and citrate, with an L/S ratio of $1000 \mathrm{~mL} / \mathrm{g}$. All of the initial and final $\mathrm{pH}$ of the solution fell within 3.4-8.7. As shown in Table 4, there were no significant decreases in phosphate removal with chloride and nitrate even when the anions were 300 folds by mole in excess of phosphate. Only bicarbonate, sulfate, and citrate ions could hamper phosphate removal. This finding is in agreement with our earlier report on Cu-EDA-SAMMS that anion binding is a function of anion basicity [48]. However, as illustrated in Table 4, Fe-EDA-SAMMS was much less affected by the presence of coexisting anions than the commercial $\mathrm{AG}^{\circ} 1-\mathrm{X} 8$ resin, having simple quaternary ammonium as the binding site, which has little selectivity. Evidently, the addition of Fe(III) to the EDA group increases selectivity of the binding site for phosphate compared to simple ammonium which acts as an anion exchanger. 


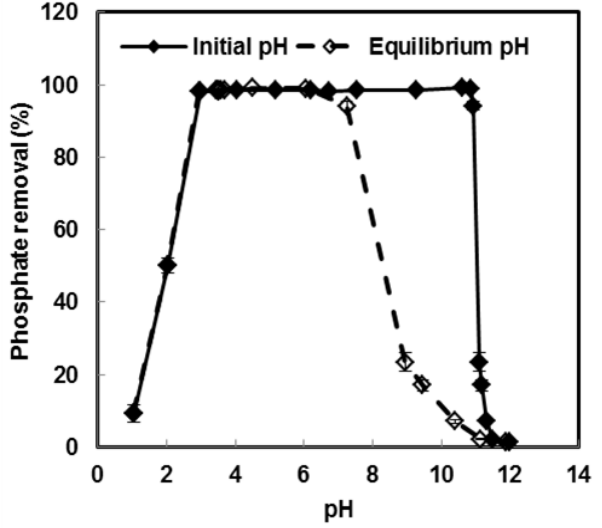

Figure 3: Effect of $\mathrm{pH}$ on phosphate removal efficiency of Fe-EDA-SAMMS Initial phosphate concentration of $6 \mathrm{mg}$ phosphate/L (from $\mathrm{K}_{2} \mathrm{HPO}_{4}$ ) and $\mathrm{L} / \mathrm{S}$ ratio of $2000 \mathrm{~mL} / \mathrm{g}$. Closed symbols and solid-line represent initial $\mathrm{pH}$ of phosphate solutions, while opened symbols and dash-line represent equilibrium $\mathrm{pH}$.

Compared to Fe-EDA-SAMMS, simple anion exchangers were much more affected by increasing concentrations of the interfering anions. As shown in Figure 2B, when used to capture the same phosphate concentration $(3 \mathrm{mg} / \mathrm{L})$ but with higher anion content (i.e., SIF containing $0.145 \mathrm{M} \mathrm{Cl}^{-}$and $0.008 \mathrm{M} \mathrm{HCO}_{3}^{-}(\mathrm{pH} 6.3)$ ), Fe-EDASAMMS could reach $80 \%$ removal within $5 \mathrm{~min}$ and $88 \%$ after 1 hour. On the contrary, both Sevelamer $\mathrm{HCl}$ and $\mathrm{AG}^{\circ} 1-\mathrm{X} 8$ resin were largely hindered by the anions such that only a total of $40 \%$ and $0 \%$ of phosphate could be removed by Sevelamer $\mathrm{HCl}$ and $\mathrm{AG}^{\circ} 1-\mathrm{X} 8$ resin, respectively. Compared to phosphate removal in DI water (Figure 2A), the Fe-EDASAMMS efficacy was reduced only by $10 \%$, while that of Sevelamer $\mathrm{HCl}$ and $\mathrm{AG}^{\circ} 1-\mathrm{X} 8$ was reduced by $60 \%$ and $100 \%$, respectively. In short, Figure 2B confirms that Fe-EDA-SAMMS with amine-chelated Fe(III) ion as the key functional group has better selectivity for phosphate (over $\mathrm{Cl}^{-}$and $\mathrm{HCO}_{3}^{-}$) than Sevelamer $\mathrm{HCl}$ and $\mathrm{AG}^{*} 1-\mathrm{X} 8$, with primary amine and quaternary ammonium as functional groups, respectively. This suggests a great potential of Fe-EDA-SAMMS over Sevelamer HCl as an oral phosphate binder.

\section{Effect of pH on phosphate capture}

The effect of $\mathrm{pH}$ on phosphate capture on Fe-EDA-SAMMS was measured in a $6 \mathrm{mg} / \mathrm{L}$ phosphate solution of varied $\mathrm{pHs}$ with an $\mathrm{L} / \mathrm{S}$ ratio of $2000 \mathrm{~mL} / \mathrm{g}$. Figure 3 shows the phosphate removal by Fe-EDASAMMS as a function of initial $\mathrm{pH}$ (closed symbol) and equilibrium $\mathrm{pH}$ (open symbol). Fe-EDA-SAMMS showed $>99 \%$ phosphate removal in large $\mathrm{pH}$ range of 3.0 to 11.0 (as initial $\mathrm{pH}$ ). Phosphate removal by Fe-EDA-SAMMS resulted in a drop of solution $\mathrm{pH}$ (see initial $\mathrm{pH}$ vs. equilibrium $\mathrm{pH}$ ), especially when $\mathrm{pH}>8.0$. Based on equilibrium $\mathrm{pH}$, $>98 \%$ of phosphate was removed between $\mathrm{pH}$ of 3.0 and 7.0 , and \% removal decreased sharply outside of this $\mathrm{pH}$ range. Phosphate is a polyprotic acid and has 3 dissociation constants $\left(\mathrm{pK}_{\mathrm{a} 1}=2.14, \mathrm{pK}_{\mathrm{a} 2}=7.20\right.$, $\mathrm{pK}_{\mathrm{a} 3}=12.32$ ) [49]. It can exist in 4 species in the system: $\mathrm{H}_{3} \mathrm{PO}_{4}, \mathrm{H}_{2} \mathrm{PO}_{4}^{-}$, $\mathrm{HPO}_{4}^{2-}$ and $\mathrm{PO}_{4}^{3-}$. When the $\mathrm{pH}$ is lower than 2.1 , the predominant species is neutral phosphoric acid $\left(\mathrm{H}_{3} \mathrm{PO}_{4}\right)$. At pH between 2.1 and 7.2, the main species is $\mathrm{H}_{2} \mathrm{PO}_{4}^{-}$monovalent, whereas $\mathrm{pH}$ between 7.2 and 12.3 , the predominant species is $\mathrm{HPO}_{4}^{2-}$ divalent. These iron-aminefunctionalized sorbent materials seem to preferably bind to $\mathrm{H}_{2} \mathrm{PO}_{4}$ $[20,50]$, which agrees well with our data where the phosphate capture was best in the $\mathrm{pH}$ range of $3.0-7.0$. In Figure 3, between equilibrium pH 7.0 and 9.0, Fe-EDA-SAMMS could capture some phosphate, which mostly are in the form of $\mathrm{HPO}_{4}^{2-}$. When considering initial $\mathrm{pH}$, our FeEDA-SAMMS had a larger operating $\mathrm{pH}$ window ( $\mathrm{pH} 2.0$ - 11.0) than Fe-diamino-functionalized SBA-15 with an operating initial $\mathrm{pH}$ of 3.0 - 6.0 [22] and ammonium-functionalized MCM-48 with an operating initial $\mathrm{pH}$ of $4.0-6.0$ [21].

\section{Flow removal of phosphate and regeneration of Fe-EDA- SAMMS}

In a field deployed water treatment system, the ability to regenerate and reuse sorbent materials is highly desirable for cost-effectiveness. As mentioned earlier, the $\mathrm{pK}_{\mathrm{al}}$ of phosphoric acid is 2.14 [49], so at $\mathrm{pHs}$ below 2.0, phosphate exists primarily as the neutral phosphoric acid, meaning there is no Coulombic driver for binding to a metal cation. Thus we chose to evaluate the efficacy of a mild acid wash for stripping the bound phosphate from Fe-EDA-SAMMS. Fe-EDA-SAMMS was operated in a packed bed column allowing phosphate capture in a flow system. A $3 \mathrm{mg} / \mathrm{L}$ phosphate solution was flowed through the $0.01 \mathrm{~g}$ of Fe-EDA-SAMMS at a flow rate of $2 \mathrm{~mL} / \mathrm{min}$ to allow phosphate capture by the sorbent bed. Regeneration was performed with 0.2 $\mathrm{M} \mathrm{HCl}$ at the same flow rate to leach captured phosphate, followed by $\mathrm{pH}$ equilibration of the bed with $0.01 \mathrm{M}$ sodium acetate. Results are presented in Figure 4. The Fe-EDA-SAMMS captured $2.96 \mathrm{mg}$ phosphate/g which accounted for more than $95 \%$ of the initial phosphate solution. The subsequent cycles on regenerated material captured at an average of $2.85 \mathrm{mg}$ phosphate/g (93\% of initial solution). The amount of bound phosphate leached out by $0.2 \mathrm{M} \mathrm{HCl}$ was an average of 2.53 mg phosphate/g (88.5\%). This confirmed that the condition used was sufficient to elute most of the captured phosphate under flow conditions. The amount of Fe leached out from acid treatment in each cycle was at an average of $2.8 \%$ of the total amount of Fe on original FeEDA-SAMMS. These experiments also showed that Fe-EDA-SAMMS is stable and can withstand exposure to $0.2 \mathrm{M} \mathrm{HCl}$ used to strip off bound phosphate. The performance (Figure 4) in terms of \% removal efficacy was maintained after 10 cycles of study, indicating that most of the binding sites were preserved after the acid elution.

\section{Cytotoxicity of Fe-EDA-SAMMS to intestinal tissue culture cells}

We sought to establish a safety profile for Fe-EDA-SAMMS in vitro. The Caco-2 cell line resembles the epithelial cells lining the small intestine both morphologically and functionally and has been previously used to establish drug safety profile of several oral drugs $[32,51]$. We found that Fe-EDA-SAMMS was well-tolerated by Caco-2

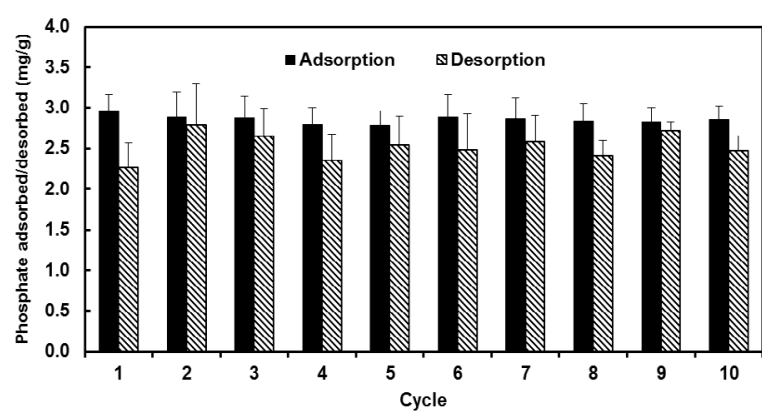

Figure 4: Adsorption and desorption of phosphate on Fe-EDA-SAMMS. During the adsorption process, $10 \mathrm{~mL}$ of $3 \mathrm{mg}$ phosphate/L (from $\mathrm{KH}_{2} \mathrm{PO}$ ) $\mathrm{pH} 5.3$ was pushed through a $0.01 \mathrm{~g}$ of Fe-EDA-SAMMS at a flow rate of 2 $\mathrm{mL} / \mathrm{min}$, followed by $10 \mathrm{~mL}$ of $0.2 \mathrm{M} \mathrm{HCl}$ at $2 \mathrm{~mL} / \mathrm{min}$ for stripping off bound phosphate (desorption step). 


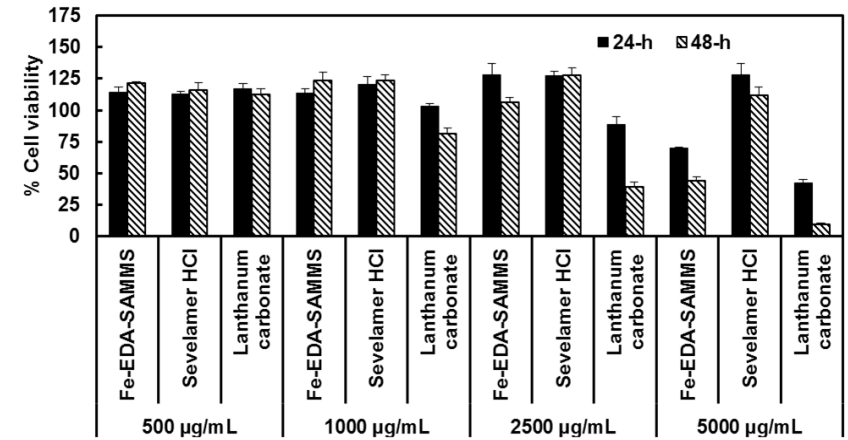

Figure 5: Cell viability of Caco-2 cells after $24 \mathrm{~h}$ (solid bar) and $48 \mathrm{~h}$ (striped bar) exposures to individual materials; Fe-EDA-SAMMS, Sevelamer $\mathrm{HCl}$ (Renagel), or Lanthanum carbonate (Fosrenol) at indicated dose range.
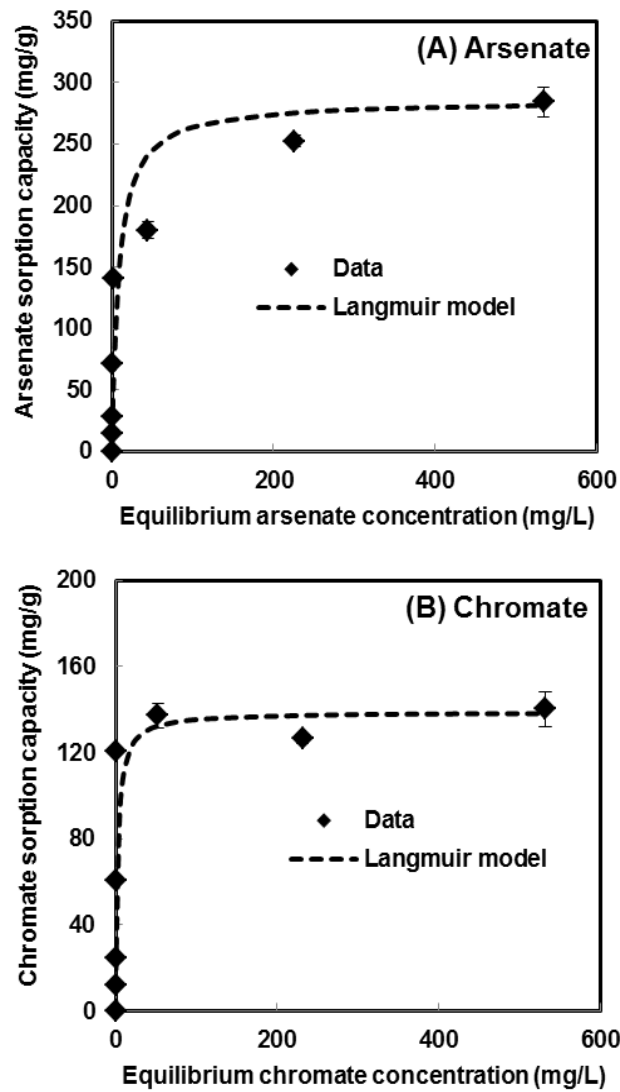

Figure 6: Adsorption isotherm of arsenate $(\mathrm{A})$ and chromate $(\mathrm{B})$ on Fe-EDASAMMS in DI water ( $\mathrm{pH} 7.5)$, L/S of $2000 \mathrm{~mL} / \mathrm{g}$, symbols represent data and dash-line represents Langmuir isotherm fitting.

cells and did not cause significant toxicity up to $2500 \mu \mathrm{g} / \mathrm{mL}$ both for $24 \mathrm{~h}$ and $48 \mathrm{~h}$ of contact time while Sevelamer $\mathrm{HCl}$ was tolerated up to $5000 \mu \mathrm{g} / \mathrm{mL}$ (Figure 5). Fe-EDA-SAMMS was better tolerated than another prescribed oral phosphate binder, lanthanum carbonate, which started to show some toxicity at $1000 \mu \mathrm{g} / \mathrm{mL}$. Lanthanum carbonate is an inorganic salt which is dissociated in GI tract and is readily taken up by cells, making it more toxic to cells. On the other hand, the micronscale particle sizes of Fe-EDA-SAMMS and Sevelamer $\mathrm{HCl}$ (both having similar zeta potential of $30-40 \mathrm{mV}$ in water) made them not easily taken up by the cells, which limited cytotoxicity. This agrees with our previous work [31] that SAMMS (with thiol groups) having particle size of $1-2 \mu \mathrm{m}$ could be taken up by Caco- 2 cells after $3 \mathrm{~h}$ of contact time whereas particles of larger size $(>5 \mu \mathrm{m})$ were not. This is why we chose SAMMS of $20-75 \mu \mathrm{m}$ to avoid uptake by the GI tract. Increases in dose and contact time might enhance the uptake, resulting in the increased cytotoxicity of SAMMS at high dose (e.g., at $5000 \mu \mathrm{g} / \mathrm{mL}$ at $24-48$ h contact time, Figure 5). Preliminary clearance study of one SAMMS material (with thiol groups) of the same particle sizes (20 - 75 $\mu \mathrm{m}$ ) after oral administration to rats (given as $0.1 \%$ by weight of food for $24 \mathrm{~h}, 4$ animals) indicates that most of SAMMS administered was recovered (i.e., $91 \%$ within 2 days and $99 \%$ within 4 days, by silicon $(\mathrm{Si})$ analysis of daily collected feces and urine using an ICP-MS). Out of the total Si excreted after 4 days, 0.98 fraction was found in feces, and 0.2 fraction was found in urine. Hence, the majority of SAMMS material does not absorb to the body and is cleared through fecal excretion.

\section{Arsenate and chromate adsorption on Fe-EDA-SAMMS}

Although not a main focus of this paper, we have found Fe-EDASAMMS to be very efficacious at capturing arsenate and chromate, the two most hazardous oxometallate anions found in environmental water bodies [52]. We have previously shown that Cu-EDA-SAMMS was able to adsorb both arsenate and chromate in aqueous solution at high capacity [26]. With the improved iron incorporation method reported in this work, we chose to evaluate whether arsenate and chromate adsorptions could be improved as well. We found that the new Fe-EDA-SAMMS has a capacity of $286 \mathrm{mg} / \mathrm{g}$ for arsenate and 139 $\mathrm{mg} / \mathrm{g}$ for chromate in DI water ( $\mathrm{pH} 7.5$ ) (Figures 6A-B), representing a significant improvement over the Cu-EDA-SAMMS's capacity for arsenate (vs. $140 \mathrm{mg} / \mathrm{g}$ ), but same for chromate (vs. $130 \mathrm{mg} / \mathrm{g}$ ).

\section{Conclusions}

The improved Fe-EDA-SAMMS has great potential for both environmental phosphate removal and as an oral phosphate binder. Using warm acetonitrile as a solvent during the $\mathrm{Fe}$ (III) incorporation step eliminated the issue of competing EDA ligand protonation and resulted in higher quality sorbent materials. The new material had (i) 4-fold higher phosphate binding capacity, (ii) high selectivity to phosphate in simulated gastrointestinal fluids, (iii) rapid phosphate binding kinetics, (iv) wide range of working solution $\mathrm{pH}$ suitable for phosphate removal in stomach and intestinal tract as well as in wastewater, (v) smaller interference from competing anions, (vi) low cytotoxicity to in vitro intestinal epithelial cell model, and (vii) an enhanced ability to bind arsenate and chromate.

\section{Acknowledgement}

Research reported here was supported by awards to Yantasee from the National Institute of General Medical Sciences (NIGMS; R01GM089918), the National Institute of Diabetes and Digestive and Kidney Diseases (NIDDK; R41DK094571), and Oregon Nanoscience and Microtechnologies Institute (ONAMI). The content is solely the responsibility of the authors and does not necessarily represent the official views of the National Institutes of Health.

\section{References}

1. Grassmann A, Gioberge S, Moeller S, Brown G (2005) ESRD patients in 2004 global overview of patient numbers, treatment modalities and associated trends. Nephrol Dial Transplant 20: 2587-2593.

2. Hutchison AJ, Smith CP, Brenchley PE (2011) Pharmacology, efficacy and safety of oral phosphate binders. Nat Rev Nephrol 7: 578-589.

3. Hutchison AJ, Whitehouse RW, Freemont AJ, Adams JE, Mawer EB, et al. (1994) Histological, radiological, and biochemical features of the adynamic bone lesion in continuous ambulatory peritoneal dialysis patients. Am J Nephrol 14: 19-29. 
Citation: Sangvanich T, Ngamcherdtrakul W, Lee R, Morry J, Castro D, et al. (2014) Nanoporous Sorbent Material as an Oral Phosphate Binder and for Aqueous Phosphate, Chromate, and Arsenate Removal. J Nanomed Nanotechnol 5: 222. doi: 10.4172/2157-7439.1000222

4. Goodman WG, London G, Amann K, Block GA, Giachelli C, et al. (2004) Vascular calcification in chronic kidney disease. Am J Kidney Dis 43: 572-579.

5. Tonelli M, Pannu N, Manns B (2010) Oral phosphate binders in patients with kidney failure. N Engl J Med 362: 1312-1324.

6. Yang WC, Yang CS, Hou CC, Wu TH, Young EW, et al. (2002) An open-label, crossover study of a new phosphate-binding agent in haemodialysis patients: ferric citrate. Nephrol Dial Transplant 17: 265-270.

7. Gibson GR, Carlson R, Simpson J, Smeltzer E, Gerritson J, et al. (2000) Nutrient Criteria Technical Guidance Manual: Rivers and Streams.

8. Gibson GR, Carlson R, Simpson J, Smeltzer E, Gerritson J, et al. (2000) Nutrient Criteria Technical Guidance Manual: Lakes and Reservoirs.

9. United States Environmental Protection Agency (2001) Nutrient Criteria Technical Guidance Manual: Estuarine and Coastal Marine Waters.

10. Morse GK, Brett SW, Guy JA, Lester JN (1998) Review: Phosphorus Removal and Recovery Technologies. Sci Total Environ 212: 69-81.

11. Xu K, Deng T, Li C, Niu J (2013) Phosphate Removal from Aqueous Solution Using Fly Ash Modified with Magnetic Fe-Zn Bimetal Oxide. Adv Mater Res 621: 296-302.

12. Tian S, Jiang P, Ning P, Su Y (2009) Enhanced Adsorption Removal of Phosphate from Water by Mixed Lanthanum/aluminum Pillared Montmorillonite. Chem Eng J 151: 141-148.

13. Zhang G Liu H, Liu R, Qu J (2009) Removal of phosphate from water by a FeMn binary oxide adsorbent. J Colloid Interface Sci 335: 168-174.

14. Zhang Q, Du Q, Jiao T, Pan B, Zhang Z, et al. (2013) Selective Removal of Phosphate in Waters Using a Novel of Cation Adsorbent: Zirconium Phosphate (ZrP) Behavior and Mechanism. Chem Eng J 221: 315-321.

15. Long F, Gong JL, Zeng GM, Chen L, Wang XY, et al. (2011) Removal of Phosphate from Aqueous Solution by Magnetic Fe-Zr Binary Oxide. Chem Eng J 171: 448-455.

16. Ren X Yang S, Tan X, Chen C, Sheng G, et al. (2012) Mutual effects of copper and phosphate on their interaction with $\mathrm{Y}-\mathrm{Al}_{2} \mathrm{O}_{3}$ : combined batch macroscopic experiments with DFT calculations. J Hazard Mater 237-238: 199-208.

17. Oliveira M, Machado AV, Nogueira R (2012) Phosphorus Removal from Eutrophic Waters with an Aluminium Hybrid Nanocomposite. Water Air Soi Pollut 223: 4831-4840.

18. Dai J, Yang $H$, Yan $H$, Shangguan $Y$, Zheng Q, et al. (2011) Phosphate Adsorption from Aqueous Solutions by Disused Adsorbents: Chitosan Hydrogel Beads after the Removal of Copper(II). Chem Eng J 166: 970-977.

19. Gandhi MR Meenakshi S (2012) Preparation and characterization of La(III) encapsulated silica gel/chitosan composite and its metal uptake studies. J Hazard Mater 203-204: 29-37.

20. Chouyyok W Wiacek RJ, Pattamakomsan K, Sangvanich T, Grudzien RM, et al. (2010) Phosphate removal by anion binding on functionalized nanoporous sorbents. Environ Sci Technol 44: 3073-3078.

21. Hamoudi S, Saad R, Belkacemi K (2007) Adsorptive Removal of Phosphate and Nitrate Anions from Aqueous Solutions Using Ammonium-Functionalized Mesoporous Silica. Ind Eng Chem Res 46: 8806-8812.

22. Huang WY, Li D, Yang J, Liu ZQ, Zhu Y, et al. (2013) One-pot Synthesis of Fe(III)-coordinated Diamino-functionalized Mesoporous Silica: Effect of Functionalization Degrees on Structures and Phosphate Adsorption. Microporous Mesoporous Mater 170: 200-210.

23. Zhang J Shen Z, Mei Z, Li S, Wang W (2011) Removal of phosphate by Fecoordinated amino-functionalized 3D mesoporous silicates hybrid materials. $J$ Environ Sci (China) 23: 199-205.

24. Zhang J Shen Z, Shan W, Mei Z, Wang W (2011) Adsorption behavior of phosphate on lanthanum(III)-coordinated diamino-functionalized 3D hybrid mesoporous silicates material. J Hazard Mater 186: 76-83.

25. Huang W, Yang J, Zhang Y (2012) One-pot Synthesis of Mesoporous MCM41 with Different Functionalization Levels and Their Adsorption Abilities to Phosphate. Adv Mater Res 476-478: 1969-1973.

26. Fryxell GE, Liu J, Hauser TA, Nie Z, Ferris KF, et al. (1999) Design and Synthesis of Selective Mesoporous Anion Traps. Chem Mater 11: 2148-2154.

27. Feng X, Fryxell GE, Wang LQ, Kim AY, Liu J, et al. (1997) Functionalized Monolayers on Ordered Mesoporous Supports. Science 276: 923-926.
28. Yantasee W Lin Y, Hongsirikarn K, Fryxell GE, Addleman R, et al. (2007) Electrochemical sensors for the detection of lead and other toxic heavy metals: the next generation of personal exposure biomonitors. Environ Health Perspect 115: $1683-1690$.

29. Carter TG Yantasee W, Sangvanich T, Fryxell GE, Johnson DW, et al. (2008) New functional materials for heavy metal sorption: "supramolecular" attachment of thiols to mesoporous silica substrates. Chem Commun (Camb) : 5583-5585

30. Yantasee W Charnhattakorn B, Fryxell GE, Lin Y, Timchalk C, et al. (2008) Detection of $\mathrm{Cd}, \mathrm{Pb}$, and $\mathrm{Cu}$ in non-pretreated natural waters and urine with thiol functionalized mesoporous silica and Nafion composite electrodes. Ana Chim Acta 620: 55-63.

31. Yantasee W Rutledge RD, Chouyyok W, Sukwarotwat V, Orr G, et al. (2010) Functionalized nanoporous silica for the removal of heavy metals from biological systems: adsorption and application. ACS Appl Mater Interfaces 2: 2749-2758.

32. Sangvanich T Morry J, Fox C, Ngamcherdtrakul W, Goodyear S, et al. (2014) Novel oral detoxification of mercury, cadmium, and lead with thiol-modified nanoporous silica. ACS Appl Mater Interfaces 6: 5483-5493.

33. Busche B Wiacek R, Davidson J, Koonsiripaiboon V, Yantasee W, et al. (2009) Synthesis of Nanoporous Iminodiacetic Acid Sorbents for Binding Transition Metals. Inorg Chem Commun 12: 312-315.

34. Chouyyok W Shin Y, Davidson J, Samuels WD, LaFemina NH, et al. (2010) Selective removal of copper(II) from natural waters by nanoporous sorbents functionalized with chelating diamines. Environ Sci Technol 44: 6390-6395.

35. Yantasee W Fryxell GE, Lin Y, Wu H, Raymond KN, et al. (2005) Hydroxypyridinone functionalized self-assembled monolayers on nanoporous silica for sequestering lanthanide cations. J Nanosci Nanotechnol 5: 527-529.

36. Lin Y Fiskum SK, Yantasee W, Wu H, Mattigod SV, et al. (2005) Incorporation of hydroxypyridinone ligands into self-assembled monolayers on mesoporous supports for selective actinide sequestration. Environ Sci Technol 39: 13321337.

37. Yantasee W Fryxell GE, Addleman RS, Wiacek RJ, Koonsiripaiboon V, et al. (2009) Selective removal of lanthanides from natural waters, acidic streams and dialysate. J Hazard Mater 168: 1233-1238.

38. Yantasee W Sangvanich T, Creim JA, Pattamakomsan K, Wiacek RJ, et al (2010) Functional sorbents for selective capture of plutonium, americium, uranium, and thorium in blood. Health Phys 99: 413-419.

39. Yantasee W, Fryxell GE, Porter GA, Pattamakomsan K, Sukwarotwat V, et al. (2010) Novel Sorbents for Removal of Gadolinium-based Contrast Agents in Sorbent Dialysis and Hemoperfusion: Preventive Approaches to Nephrogenic Systemic Fibrosis. Nanomedicine 6: e1-e8.

40. Davidson JD Wiacek RJ, Burton S, Li XS, Fryxell GE, et al. (2012) Improved deposition and deprotection of silane tethered 3,4 hydroxypyridinone (HOPO) ligands on functionalized nanoporous silica. Inorg Chem Commun 18: 92-96.

41. Lin Y Fryxell GE, Wu H, Engelhard M (2001) Selective sorption of cesium using self-assembled monolayers on mesoporous supports. Environ Sci Technol 35 3962-3966.

42. Sangvanich T Sukwarotwat V, Wiacek RJ, Grudzien RM, Fryxell GE, et al. (2010) Selective capture of cesium and thallium from natural waters and simulated wastes with copper ferrocyanide functionalized mesoporous silica. J Hazard Mater 182: 225-231.

43. Timchalk C Creim JA, Sukwarotwat V, Wiacek R, Addleman RS, et al. (2010) In vitro and in vivo evaluation of a novel ferrocyanide functionalized nanopourous silica decorporation agent for cesium in rats. Health Phys 99: 420-429.

44. United States Pharmacopeial Convention Inc (1990) USPXXII. (22ndedn) Rockville, MD, USA.

45. United States Pharmacopeial Convention Inc (2003) USPXXVI. (26thedn) Rockville, MD, USA.

46. Rosenbaum DP Holmes-Farley SR, Mandeville WH, Pitruzzello M, Goldberg D (1997) Effect of RenaGel, a non-absorbable, cross-linked, polymeric phosphate binder, on urinary phosphorus excretion in rats. Nephrol Dial Transplant 12 961-964.

47. McConnell EL Fadda HM, Basit AW (2008) Gut instincts: explorations in intestinal physiology and drug delivery. Int J Pharm 364: 213-226.

48. Mattigod SV, Fryxell GE, Parker KE (2007) Anion Binding in Self-assembled Monolayers in Mesoporous Supports (SAMMS). Inorg Chem Commun 10: 646648. 
Citation: Sangvanich T, Ngamcherdtrakul W, Lee R, Morry J, Castro D, et al. (2014) Nanoporous Sorbent Material as an Oral Phosphate Binder and for Aqueous Phosphate, Chromate, and Arsenate Removal. J Nanomed Nanotechnol 5: 222. doi: 10.4172/2157-7439.1000222

49. Karageorgiou K Paschalis M, Anastassakis GN (2007) Removal of phosphate species from solution by adsorption onto calcite used as natural adsorbent. $J$ Hazard Mater 139: 447-452.

50. Yokoi T, Tatsumi T, Yoshitake H (2004) Fe3+ Cordinated to Amino-functionalized MCM-41: An Adsorbent for the Toxic Oxyanions with High Capacity, Resistibility to Inhibiting Anions, and Reusability after a Simple Treatment. J Colloid Interface Sci 274: 451-457.
51. Bhardwaj RK Glaeser H, Becquemont L, Klotz U, Gupta SK, et al. (2002) Piperine, a major constituent of black pepper, inhibits human P-glycoprotein and CYP3A4. J Pharmacol Exp Ther 302: 645-650.

52. Yoshitake H, Yokoi T, Tatsumi T (2002) Adsorption of Chromate and Arsenate by Amino-Functionalized MCM-41 and SBA-1. Chem Mater 14: 4603-4610. 